\title{
LOCALIS
}

\section{........................ Evidence in Civil Law - Romania}

\author{
Author: \\ Sebastian Spinei
}




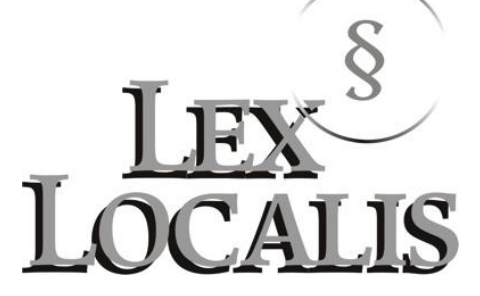




\section{(C) Institute for Local Self-Government and Public Procurement Maribor}

All rights reserved. No part of this book may be reprinted or reproduced or utilized in any form or by any electronic, mechanical, or other means, now known or hereafter invented, including photocopying and recording, or in any information storage or retriveal system, without permission in writing from the publisher.

Title: $\quad$ Evidence in Civil Law - Romania

Author: Sebastian Spinei

First published 2015 by

Institute for Local Self-Government and Public Procurement Maribor

Grajska ulica 7, 2000 Maribor, Slovenia

www.lex-localis.press, info@lex-localis.press

Book Series: Law \& Society

Series Editor: Tomaž Keresteš

CIP - Kataložni zapis o publikaciji

Narodna in univerzitetna knjižnica, Ljubljana

$347(498)(0.034 .2)$

SPINEI, Sebastian

Evidence in civil law - Romania [Elektronski vir] / Sebastian Spinei. - El. knjiga. - Maribor : Institute for Local Self-Government and Public Procurement, 2015. - (Lex localis) (Book series Law \& society)

Način dostopa (URL): http://books.lex-localis.press/evidenceincivillaw/romania

ISBN 978-961-6842-56-3 (epub)

281129984

Price: free copy

This project has been funded with support from the European Commission. This publication reflects the views only of the authors, and the Commission cannot be held responsible for any use which may be made of the information contained therein.

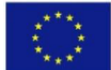

With the support of the Civil Justice Programme of the European Union 


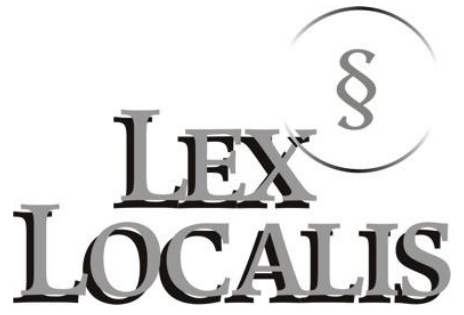

Evidence in Civil Law - Romania

Sebastian Spinei 



\title{
Evidence in Civil Law - Romania
}

\section{SEBASTIAN SPINEI}

\begin{abstract}
This study is offering a review of the most important institutions of the Romanian law of evidence: the fundamental principles of civil procedure, as well as the general principles of evidence taking; an analysis of the various means of evidence, and of the rules regarding the taking of evidence; some specific issues such as the unlawful evidence, the costs, language and translation in the process of the taking of evidence, are also examined.
\end{abstract}

KEYWORDS: - civil procedure - fundamental principles - rules of evidence $\cdot$ means of evidence

Correspondence Address: Sebastian Spinei, Ph.D., Associate Professor, Faculty of Law, Lucian Blaga University, 550324, Calea Dumbrăvii no. 34, Sibiu, Romania, email: sebastian.spinei@ulbsibiu.ro. 


\section{Sebastian Spinei}

Author Biography Associate Professor of Civil Procedure, Civil Enforcement, Judicial Systems and Legal Profession at the Faculty of Law of Lucian Blaga University in Sibiu, Romania. Lawyer, registered with the Sibiu Bar Association. Member of the International Association of Procedural Law (IAPL). Member of the Scientific Committees or Editorial Boards of several Law journals in Romania.

Author or coauthor of a number of articles and books in the fields of Civil Procedure and the legal profession. Lectures and conference presentations in Romania and abroad. Graduate (1996) and PhD (2007) of the Faculty of Law of Lucian Blaga University in Sibiu. 


\section{Foreword}

Evidence and the rules of evidence hold an essential position with regard to the trial: judicis est judicare secundum allegata et probata. This is why an analysis of this topic is never an outdated proposition. All the more, the comparison of different national legal systems is always offering perspective, criteria for evaluation and suggestions for improvement.

This study was initially written as a national report within the EU project 'Dimensions of Evidence in European Civil Procedure' (supported by the European Commission under the Specific Programme Civil Justice). That context, namely the association of a number of studies on this same topic, is furthermore supporting the legitimacy and utility of the present monograph and of the others in the series.

The Romanian system of evidentiary rules followed initially the French model. At a later time, the Austrian inspired notion of the active judge was introduced, followed in the 1950 's by the principle of the material truth, very much treasured in the Socialist systems.

The new Code of Civil procedure (which entered into force in 2013) tried to rearrange the rules of evidence, to update them to the proper standards of a modern civil justice system. Apart maybe from only a few inconsistencies and omissions, the result is a correct and dependable set of rules. 


Evidence in Civil Law - Romania

S. Spinei

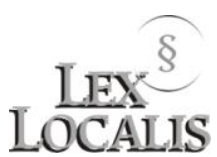

\section{Contents}

Part I ........................................................................................... 1

$1 \quad$ Fundamental Principles of Civil Procedure ............................................. 1

1.1 Principle of Free Disposition of the Parties and Officiality

Principle....

1.2 Adversarial and Inquisitorial Principle .................................................. 2

1.3 Hearing of Both Parties Principle (audiatur et alter pars) Contradictory Principle........................................................................ 3

1.4 Principle of Orality - Right to Oral Stage of Procedure, Principle of Written Form ......................................................................................... 4

1.5 Principle of Directness .......................................................................... 5

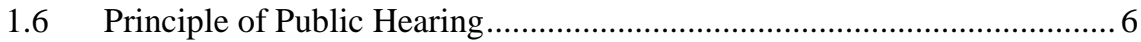

1.7 Other General Principles .................................................................... 6

2 General Principles of Evidence Taking .................................................. 6

$2.1 \quad$ Free Assessment of Evidence ............................................................... 6

2.2 Relevance of Material Truth ................................................................... 7

2.3. Other General Principles Regarding Evidence Taking ............................. 8

3 Evidence in General ............................................................................ 9

$4 \quad$ General Rule on the Burden of Proof................................................ 11

$5 \quad$ Written Evidence ......................................................................... 13

$6 \quad$ Witnesses .................................................................................... 14

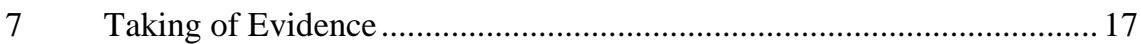

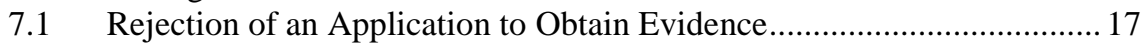

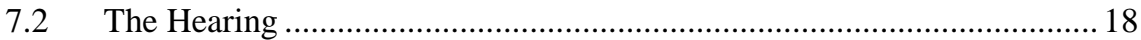

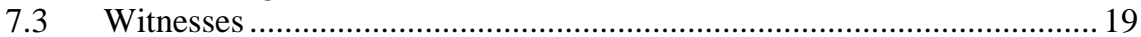

7.4 Expert Witnesses ........................................................................... 19

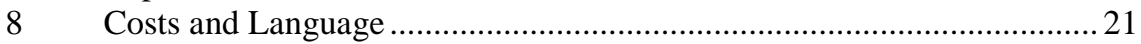

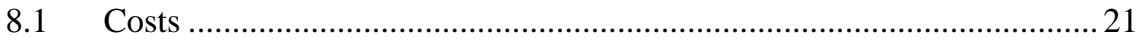

8.2 Language and Translation................................................................ 22

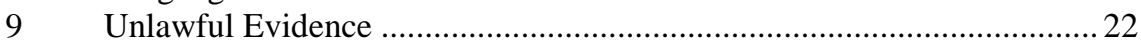

10 The Report about the Regulation No 1206/2001 .................................... 23

11 Table of Authorities ........................................................................ 24

Part II - Synoptical Presentation...................................................... 25

1 Synoptic Tables ....................................................................... 25

1.1 Ordinary/Common Civil Procedure Timeline..................................... 25

1.2 Basics about Legal Interpretation in Romanian Legal System ............... 27

1.3 Functional Comparison ................................................................ 27

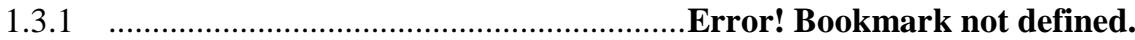

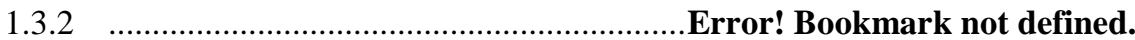

References.................................................................................... 31 

Evidence in Civil Law - Romania

S. Spinei

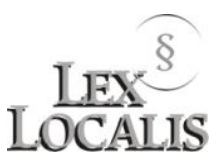

\section{Part I}

\section{Fundamental Principles of Civil Procedure}

The New Romanian Code of Civil Procedure (henceforth, also NCPC) ${ }^{2}$ comprises a whole Preliminary Title dedicated to the fundamental principles of civil procedure. The Principles were always enunciated by the legal writing ${ }^{3}$, some of them resulted from disparate texts of the Code, others from constitutional texts, but the new Code sets them out in an explicit and concentrated manner.

\subsection{Principle of Free Disposition of the Parties and Officiality Principle}

One of the fundamental principles governing Romanian civil procedure is the principle of party disposition (principiul disponibilității).

The principle is established by art. 9 NCPC, which states that:

The civil process is started by the demand/claim of the interested person.

The object and the limits of the process are set by the claims and defences of the parties. The party can withdraw its claim, renounce the disputed right, acquiesce to the claim, end the dispute by reaching a settlement (...). ${ }^{4}$

The Court is bound by the claims of the parties, it cannot decide extra and ultra petita, in other words it cannot award something that was not demanded by the party ${ }^{5}$.

In principle, all the facts must be presented in the preliminary (written) stage of the trial, that is in the introductory claim, in the statement of defence, in the response to the statement of defence and, if it is the case, in the counterclaim.

\footnotetext{
${ }^{2}$ The NCPC came into force on $15^{\text {th }}$ of February 2013.

${ }^{3}$ See Ioan Leş, Tratat de drept procesual civil, p. 39-65 (5th ed., C.H. Beck, Bucharest 2010); Ion Deleanu, Tratat de procedură civilă, vol. I, p. 136-158 (Wolters Kluwer Romania 2010); Arthur Hilsenrad, Ilie Stoenescu, Procesul civil în RPR, p. 35-57 (Editura Ştiințifică, 1957).

${ }^{4}$ See also Leş 2010, p. 61-62; Ion Deleanu, Tratat de procedură civilă, p. 32 (2nd ed., C.H. Beck, Bucharest 2007).

${ }^{5}$ A court decision that rules in such a manner will be set aside by the superior court. See also art. 22 para. 6 NCPC.
} 
New claims ${ }^{6}$ can be submitted only in limine litis, that is only until the first hearing ${ }^{7}$. After this moment, a new claim can be submitted only if all the parties agree to such submission.

Evidence must be submitted in the written phase. Exceptionally, new evidence can be submitted later in the first instance court, only if: the necessity of the evidence is determined by the modification of the claim (which must be submitted until the first hearing); the necessity of the evidence appears during the trial and the party was not able to anticipate it; the party was unable to submit the evidence for solidly justifiable reasons; the taking of the evidence does not determine the delay of the trial; or if all the parties agree to the taking of the evidence. ${ }^{8}$

On the other hand, the Court is not bound by the party submissions regarding the evidence. According to art. 22 para. 2 NCPC, the Court can order the taking of any evidence it considers necessary, even if the parties oppose.

\subsection{Adversarial and Inquisitorial Principle}

Another traditional principle ${ }^{9}$ of Romanian civil procedure is that of the active role of the Judge (rolul activ).

The parties have primarily the duty to prove their claims and defences ${ }^{10}$. Nevertheless, according to art. 22 para. 2 NCPC, the judge has the duty to persist, using all legal means, in preventing any error in finding the truth in the case. To this end, he is entitled to order the taking of the evidence it considers necessary, even if the parties oppose ${ }^{11}$.

The judge also has the power to require the parties to offer clarifications regarding the facts and legal grounds they assert, to put into the parties' discussion any legal or factual circumstances, even if these are not specified in the claim or in the defence statement, and to order any other legal measures, even if the parties oppose ${ }^{12}$. Furthermore, the

\footnotetext{
${ }^{6}$ For any claim, the party must state its grounds - facts and law.

${ }^{7}$ The first court session when the plaintiff is properly (legally) summoned - see art. 204 NCPC.

${ }^{8}$ See art. 254 NCPC. Despite these rules, new evidence may be allowed or ordered in the first appeal.

${ }^{9}$ See Sebastian Spinei, Rules of Evidence in Romanian Civil Procedure and their impact on Truth and Efficiency, in C.H. van Rhee, A. Uzelac (eds.), Truth and Efficiency in Civil Litigation, p. 261, 267-269 (Intersentia 2012); Viorel Mihai Ciobanu, in V.M. Ciobanu, Marian Nicolae (coord.), Noul cod de procedură civilă: comentat şi adnotat, p. 55-60 (Universul Juridic, 2013).

${ }^{10}$ Art. 10 and 254 NCPC.

${ }^{11}$ See also art. 254 para. 5 NCPC. But, according to art. 254 para. 6 NCPC, the parties cannot raise, as grounds for an appeal, the fact that the lower court did not order of its own motion the taking of evidence not proposed by the parties themselves. In my opinion, such a legal disposition calls into question the very existence (or preservation) of the active role principle (see, on this issue, infra, Relevance of material truth; also Spinei, op. cit., p. 269-271).

${ }_{12}$ Art. 22 para. 2 NCPC. See also art. 22 para 3-7.
} 
judge has to ensure the resolution of cases in an 'optimal and predictable' time, by ordering any measures prescribed by the law ${ }^{13}$.

The active role principle, even if it has traits which would allow comparison with the principle of substantive guidance (Materielle Prozessleitung), does not imply, however, features like the duty to discuss (at least not in its entirety), and not at all the duty to $\operatorname{warn}^{14}$.

The court does not produce a list of references as a special, distinct document, but it will issue an interlocutory ruling ${ }^{15}$ on the requests for evidence of the parties (which have to be filed before the first hearing ${ }^{16}$ ) or will order evidence ex officio. Such a decision will have to also mention the facts that are going to be proven ${ }^{17}$. Only the parties are precluded to submit new facts and evidence after the first hearing, while the court is empowered to further investigate during the whole trial.

\subsection{Hearing of Both Parties Principle (audiatur et alter pars) - Contradictory Principle}

The contradictory principle (principiul contradictorialității) is also one of the principles of the Civil process ${ }^{18}$. Art. 14 NCPC provides that the Court cannot decide on a claim unless the parties were either summoned or they have appeared at the trial ${ }^{19}$. The same text states that the parties have the right to argue on every issue of fact or law which was raised during the trial, and that the court has the duty to put into the debate of the parties every such issue (all the demands, exceptions and questions of fact and law). The court can give its decision only based on factual and legal grounds, clarifications and evidence that were brought to contradictory debate.

The summoning of the parties (and the service of documents) are performed, in principle, by the court (but they can also be executed by a bailiff empowered by the party).

The right of defence is considered to be a distinct principle of litigation. According to this principle, the parties have on the one hand the right to be assisted or represented by

\footnotetext{
${ }^{13}$ Art. 6 NCPC.

${ }^{14}$ The judge has the power to ask questions. See, for German procedure, Ulrich Haas, The Relationship between the Judge and the Parties under German Law, in Volker Lipp, Halvard Haukeland Fredriksen (eds.), Reforms of Civil Procedure in Germany and Norway, p. 99-103 (Mohr Siebeck, 2011).

${ }^{15}$ At every hearing, the court issues a procedural document (încheiere de şedință- 'closure of the hearing') having a dual function - record of the hearing (court minutes) and interlocutory decision (a ruling on various requests and motions or an order issued of its own motion).

${ }^{16}$ The court will decide upon the evidence requests at the first hearing.

${ }^{17}$ Art. 258 para. 2 NCPC.

${ }^{18}$ Leş 2010, p. 58-59.

${ }^{19}$ Same rule is also provided in art. 153 NCPC. There are also some exceptions - e.g. in the special procedure for urgent matters (art. 996-1001 NCPC).
} 
a lawyer or a legal counsel ${ }^{20}$, and on the other hand they can exercise all the prerogatives in order to protect their interests in the lawsuit ${ }^{21}$. Art. 13 para. 3 NCPC states that there must be ensured the posibility for the parties to participate to all stages of the trial, to have acces to the case file, to submit evidence, etc. The parties must exercise their procedural rights in good faith, according to the intended reason/purpose they were enacted for, and without violating the rights of the opposing party ${ }^{22}$.

The court can decide without the hearing of the opposite party as long as the summoning procedure was legally carried out. If both parties are absent, the court will order the staying of the trial. If the parties do not take any action to carry it forward, this kind of passivity will cause the 'extinction' of the lawsuit.

In particular situations, the absence of the party may provoke significant consequences. If the party does not appear, for example, when it was summoned to answer to the questions of the opposite party, the court may consider the absence as a recognition of the facts on which the questions were addressed ${ }^{23}$.

The possibility of entering a default judgment does not exist in the Romanian Civil procedure.

In case the right of defence is not observed, the party can appeal and obtain the setting aside of the decision and the referral of the case to the lower court.

The right to equal treatment is proclaimed in article 8 of the Code of Civil procedure, which states that the equal and non-discriminatory exercise of procedural rights is guaranteed for the parties.

The right to the same decision in the same cases is not explicitly stated by the Code. It pertains rather to the principle of the fair trial, provided (also) by art. 6 of the NCPC. The new code is intending to ensure legal certainty or the predictability of judicial decisions by assigning the Supreme Court (High Court of Cassation - Inalta Curte de Casație şi Justiție) as the only court deciding on final appeals.

\subsection{Principle of Orality - Right to Oral Stage of Procedure, Principle of Written Form}

Art. 15 NCPC states that the proceedings are held orally, except for the case where a specific legal disposition provides otherwise or if the parties are specifically requesting the case to be judged based only on the submitted documents.

\footnotetext{
${ }^{20}$ Art. 13 para. 2 NCPC. On the profession of legal counsel, see S.Spinei, Considerations on the Romanian legal profession system, in A. Uzelac, C.H. van Rhee (eds.), The Landscape of the Legal Professions in Europe and the USA: Continuity and Change, p. 41-54 (Intersentia 2011); Ioan Leş, Instituții judiciare contemporane, p. 318-346 (C.H. Beck, Bucharest, 2007).

${ }^{21}$ Leş 2010, p. 60.

${ }^{22}$ Art. 12 NCPC.

${ }^{23}$ Art. 358 NCPC.
} 
The proceedings before the first instance court have two main phases ${ }^{24}$ - the written phase, where the introductory claim, the statement of defence, the response to the statement of defence and, if it is the case, the counterclaim are submitted, and the instruction phase (cercetarea judecătorească), where the oral debates ${ }^{25}$ are held. Any procedural act in this second phase (motions and requests, arguments on procedural issues or incidents, etc.) can be performed also in writing. The instruction phase ends with the closing arguments (submissions) ${ }^{26}$. The new Code states that the parties are obliged to file, before the final hearing, their final arguments in form of written notes, without prejudice to their right to also present their arguments orally ${ }^{27}$.

\subsection{Principle of Directness}

The principle of directness is also present among the principles governing the Romanian civil process. According to this principle, the evidence is taken by the same court that judges the $\operatorname{case}^{28}$. There are also some exceptions from the principle: the 'letter/commission rogatory' (comisie rogatorie), by which a court can require assistance from another court for the taking of evidence ${ }^{29}$; the taking of evidence by lawyers or legal counsel ${ }^{30}$. Both the 'letter rogatory' and the taking of evidence by lawyers or legal counsel can be employed for the taking of any means of evidence. The latter, though, cannot be used in disputes which have a strictly personal nature (e.g. those regarding the legal capacity or family relations).

The intermediate appellate court (Tribunal or Court of Appeal) can take evidence itself. The highest appellate court (The Court of Cassation) will not take the evidence, but it will refer the case to the lower court.

The appellate courts can evaluate freely the evidence taken by the lower court.

\footnotetext{
${ }^{24}$ The appellate procedure has a similar structure.

${ }^{25}$ Oral debates will be held on the admisibility and taking of evidence, on procedural exceptions and other incidents (e.g. recusal of the judges, staying of the proceedings, extinction of the lawsuit), etc.

${ }^{26}$ See art. 389-394 NCPC.

${ }^{27}$ Art. 244 para. 2 NCPC. See also art. 244 para. 3.

${ }^{28}$ Art. 16 NCPC. See also Leş 2010, p. 63.

${ }^{29}$ Art. 261 NCPC.

${ }^{30}$ Art. 366-388 NCPC. According to arts. 368 and 388, at the first hearing, the parties may agree that their lawyers or legal counsels will perform the taking of evidence in the case. The court will grant a time limit of up to six months for the taking of evidence (but the time limit can be extended). Evidence is taken in the offices of the lawyers or in any other place agreed on by the parties. The court will decide on any procedural incident during this procedure. At the end, the lawyers will prepare bundles of documents, one for each party and one which will be filed with the court. The court will decide based on the evidence taken by the lawyers. It can also decide to take itself additional evidence.

However, it is a procedure that is seldom (if ever) used by the parties.See also Spinei 2012, p. 266-267.
} 


\subsection{Principle of Public Hearing}

The principle of public hearing is stated by art. 17 of the NCPC, according to which the hearings are held publicly, except for the cases where a legal disposition provides otherwise. The meaning of the principle is that the access of the general public in the courtroom is unrestricted ${ }^{31}$ (under the previous Code, the court could have exceptionally order the hearing to be held in the absence of the general public in case the open debates could harm the public order or morality or the parties themselves).

The NCPC seems to challenge, though, the very principle it proclaims, by establishing the rule that the instruction phase of the trial will take place not in a public court session, but in camera ${ }^{32}$.

\subsection{Other General Principles}

The new Code of Civil procedure is also mentioning other principles.

Art. 6 NCPC prescribes the right of the parties to a fair trial and to the resolution of cases in an 'optimal and predictable' time. To ensure the functioning of the principle, the judge has the duty to order any measures prescribed by the law.

Art. 8 NCPC regulates the principle of the equality of the parties, stating that the parties are ensured the equal and non-discriminatory exercise of their procedural rights.

According to art. 19 of the Code, the judge designated to take on the case can only be replaced for well-founded reasons. The text expresses the principle of continuity ${ }^{33}$.

Our civil procedure does not regulate the pre-trial taking of evidence.

\section{General Principles of Evidence Taking}

\subsection{Free Assessment of Evidence}

The rule of the free assessment (the judge's conviction intime) governs the law of evidence. According to art. 264 NCPC, the judge will evaluate the evidence freely,

31 See Leş 2010, p. 56. According to art. 217 NCPC, the minors are not admitted in the courtroom. According to arts. 31, 32, 47, Decision no. 482/2012 of the Plenary Assembly of the Superior Council of Magistracy, the public hearings are always accessible for the media. Live coverage of the entire hearing is not allowed. The photographing, video and audio recording of only some specifically prescribed phases of the hearing (the entering of the Court, the opening of the hearing, the closing arguments, the reading of the judgment) or other moments are possible with permission of the presiding judge and the consent of the person involved. The broadcasting of the photos or recordings is only allowed if permission is granted by the presiding judge and with the consent of the persons concerned.

${ }^{32}$ Art. 240 NCPC. The entering into force of this rule was postponed, however, until 2016 (Law no. $2 / 2013$, art. XII).

${ }^{33}$ See Leş 2010, p. 63-64. 
which means that no method of proof is considered to be stronger than others, and that the facts are considered as established or not according to appreciation of the judge ${ }^{34}$.

The appreciation of the court is not guided by any extrinsic formal rules or guidelines, being entirely based on the inner conviction of the judge.

\subsection{Relevance of Material Truth}

The principle of material truth was traditionally proclaimed in our civil procedure. During the socialist regime it was presented as a landmark innovation, one that fundamentally separated socialist justice from what was practiced in the capitalist system $^{35}$.

In that period, the principle was implemented through consistent specific rules. According to this principle, the judge had the duty to persist, using all legal means, in preventing any error in finding the truth in the case. In order to be able to fulfil this duty, he had the power to order the taking of any evidence it considers necessary, even if the parties oppose. And, finally, the lack of judicial active role represented grounds for appeal ${ }^{36}$.

The principle was maintained after the fall of the Communist regime, and it is reiterated by the NCPC: art. 22 para. 2 reproduces almost ad litteram the texts of the previous Code regarding the duty of the judge to find the truth and its power to order any evidence. But art. 254 para. 6 NCPC states that the parties cannot raise, as grounds for appeal, the lack of active role - that is, the fact that the lower court did not order sua sponte the taking of evidence not proposed by the parties themselves ${ }^{37}$.

It seems, under these rules, that the correctness of the fact finding will have to rely on the parties effort to prove their allegations, and that the material truth was actually abandoned in favour of the 'judicial truth', once criticised by the socialist ideology.

The court will appreciate freely, according to its conviction, whether or not the truth was established.

The alleged errors in finding the truth can be brought by the parties before the appellate court.

\footnotetext{
${ }^{34}$ See also infra, Evidence in general.

${ }^{35}$ In reality, the principle was introduced already in the early and mid 1900's, under the influence of the Austrian procedural legislation (see Spinei 2012, p. 263; Aurelian Ionaşcu, Probele în procesul civil, p. 60 (Editura Ştiinţifică, 1969).

${ }^{36}$ Art. 304 para. 2 point 2 of the Code of Civil Procedure, in its 1952-1993 version; see also Grațian Porumb, Codul de procedură civilă comentat şi adnotat, p. 41 (Editura Ştiințifică, 1962); V.M. Ciobanu, Drept procesual civil, p. 34 (Universitatea din Bucureşti, 1986).

${ }^{37}$ See also Leş 2010, p. 51.
} 
A number of general principles are intended to ensure the determination of the material truth: art. 14 para. 3 NCPC states that the parties have the obligation to expose all the facts of the case correctly and completely, without distorting or omitting any of them; they have also the obligation to express their opinion regarding the allegations of the opposite party $^{38}$; art. 11 NCPC stipulates the duty of any person to support the administration of justice. Some particular rules are also prescribed: the obligation to testify, the obligation of the person who holds documents or objects to present them to the $\operatorname{court}^{39}$, the obligation of any authority or person to communicate the information requested by the court ${ }^{40}$, etc.

The protection of secrecy and privacy may limit the possibility of determining the material truth. There is no obligation to give testimony for persons who are bound by an obligation of secrecy ${ }^{41}$. The court will reject a request for an order to file a document if this would cause breach of a legal obligation of confidentiality ${ }^{42}$.

Since the early 1900's, Romanian Civil Procedure establishes the rule that facts and evidence can only be introduced in limine litis - at the beginning of the trial. The New Code upholds this concept, by stating that all facts and evidence are to be submitted in the preliminary written stage of the trial (through the introductory claim, the statement of defence, the response to the statement of defence and, if it is the case, the counterclaim).

New allegations of fact can be made only until the first hearing. After this moment, a new fact can be submitted only if all the parties agree to such submission. New evidence can be proposed later in the first instance court, only in special circumstances ${ }^{43}$. Nevertheless, in the first appeal, new evidence can be taken, if the appellate court considers it necessary, which denotes a degree of inconsistency of the legislation.

\subsection{Other General Principles Regarding Evidence Taking}

The Code of Civil Procedure and the legal writing are stipulating some specific rules or conditions regarding the admissibility of evidence. The rule of the legality of evidence signifies that in order to be allowed, any means of evidence must be prescribed by the law ${ }^{44}$. For the evidence to be allowed, the fact to be proven must be credible, relevant ('pertinent') and conclusive ${ }^{45}$.

\footnotetext{
${ }^{38}$ Nevertheless, no sanctions are provided for not observing the principle.

${ }^{39}$ Arts. 10 para. 2, 293, 295 NCPC. See, also, art. 187 NCPC (which establishes fines for various procedural violations).

${ }^{40}$ See arts. 255 para. 4,187 NCPC.

${ }^{41}$ See infra, Witnesses.

${ }^{42}$ Arts. 294, 297 NCPC.

${ }^{43}$ See also, for the possibility of introducing new facts and evidence, supra, Principle of free disposition of the parties and officiality principle.

${ }^{44}$ See art. 255 NCPC; Leș 2010, p. 556.

${ }^{45}$ Ibidem; Ionaşcu, p. 34.
} 
According to the legal literature, rules of evidence are characterised by liberalism (as an expression of the principle of party initiative, which operates under the court's control and as far as the law prescribes), equality of the parties, loyalty (good faith in finding the truth) and activism (of both the parties and the court, for the finding of truth and justice) ${ }^{46}$.

\section{Evidence in General}

Our civil procedure relies on the rule of the free evaluation of evidence, which means that, in principle, no method of proof is stronger than the others. Art. 264 states that the judge will evaluate the evidence freely, according to his conviction, unless a legal disposition stipulates for the probative value of certain means of proof. For example, an 'authentic/authenticated document ${ }^{47}$ will be considered as an absolute (complete) proof of those matters personally perceived by the official that instrumented the document, (so the authenticated document is irrebuttable) until the document is declared to be false ${ }^{48}$; the proof of a legal transaction which has a value of more than (the equivalent of) $€ 60$ cannot be done with witness evidence, but only with written documents ${ }^{49}$; witness evidence is not admissible if it tends to prove against the content of a written document ${ }^{50}$.

A doctrine of the standard of proof does not exist in the Romanian procedural system. The facts will be considered as established or not according to the same concept of the judge's conviction intime ${ }^{51}$.

The means of proof are listed by the New Code of Civil Procedure in article no. 250: written documents; witness testimony; presumptions; the confession of a party (i.e., the admission/recognition of certain facts) ${ }^{52}$; expert opinions (/reports); real (/material, physical) evidence ${ }^{53}$; inspection by the judge 'on-site'; any other means prescribed by the law.

The parties do not technically testify. They can make 'confessions' or recognitions voluntarily, or as responses to the 'interrogatory' - a set of questions formulated by the other party.

A judicial recognition is valid only if it is made by a person whose legal capacity (discernment) is complete, undiminished by age or disability, and only if the recognition

\footnotetext{
${ }^{46}$ See Deleanu 2007, p. 649.

${ }^{47}$ Such as a notarial deed.

${ }^{48}$ See also Maria Fodor, in V.M. Ciobanu, M. Nicolae, p. 692-693.

${ }^{49}$ Art. 309 para. 2 NCPC.

${ }^{50}$ Art. 309 para. 4, 5 NCPC. Generally, on the free assessment of evidence, see Ionaşcu p. 75-76.

${ }^{51}$ The court has, however, the obligation to explicitly offer grounds for the decision it makes.

${ }^{52}$ See art. 348, 349 NCPC.

${ }^{53}$ See also Ionaşcu 61. Generally, on the free assessment of evidence, Ionaşcu, p. 75-76.
} 
concerns rights that the party can make full use and dispose of, that is to say transferrable rights ${ }^{54}$ : qui non potest dare non potest confiteri.

The interrogation of a party can be requested by the opposite party or it can be ordered by the court sua sponte.

A party can refuse to answer to the questioning. If the party refuses to answer without substantial grounds, the court can consider the refusal as a full recognition, or as a so called commencement of proof in writing ${ }^{55}$, which allows a completion of the evidence with witnesses or any other means of evidence ${ }^{56}$.

The party that answers to the interrogatory is not under oath.

Therefore, there is no sanction for the insincere party.

Evidence gathered trough parties testimony is evaluated according to the intimate conviction of the judge.

Certain facts can only be proven by specifically prescribed evidence: the existence of most contracts (including operations such as a cheque or a bill of exchange) can only be proven with written documents.

In some specific procedures, there are also rules prescribing that only certain means of proof can be taken: in the order for payment procedure (art. 1013-1024 NCPC), only documents can be presented as evidence; in the small claims procedure (art. 1025-1032 NCPC), the taking of evidence which leads to greater expenses than the value of the claim won't be admitted.

If a party presents during the proceedings various evidence (witnesses, authenticated documents, private documents, expert opinion, etc.), none of them will be considered $a$ priori to having greater value than the others. It is not even allowed multiple means of evidence to be taken to prove the same fact.

The value of judicial and administrative decisions as evidence differs. An administrative decision does not have res judicata authority before the civil court. A prior judicial decision on civil matters is only binding for the parties in that trial, and not for a third party. A decision rendered by a criminal court binds the civil court regarding the existence of the criminal act, the identity of the perpetrator and its culpability.

\footnotetext{
${ }^{54}$ See art. 349 NCPC. The transferrable rights are the pecuniary rights; on the contrary, the rights attached to the person and its capacity and status are not transferrable. On the other hand, the right must actually belong to the party to dispose of it.

${ }^{55}$ The original French term is commencement de preuve par écrit (see art. 1347 of the French Civil Code).

${ }^{56}$ Art. 358 NCPC.
} 
According to arts. 10 and $254 \mathrm{NCPC}$, there is a general duty of the parties to prove their claims and defences. If they fail to produce evidence, the consequence is losing the case.

There may be different consequences for not fulfilling various specific duties regarding the delivering of evidence.

For example, if a party is in possession of a document, the court will order the presentation of the document. If the party fails to comply, the court can hold as proven the allegations regarding the content of the document ${ }^{57}$. The court can also order the presentation of a document which is in possession of a third person. If the document is not produced, the court will impose a fine on that person and can order compensation for delay ${ }^{58}$. Fines can be imposed for various other breaches ${ }^{59}$. If the party does not appear in court when it was summoned to answer to the questions of the opposite party, the court may consider the absence as a recognition of the facts ${ }^{60}$. If a party fails to produce evidence after such an action was ordered, the court can impose forfeiture of the right to bring that evidence.

\section{General Rule on the Burden of Proof}

The issue of the burden of proof (as duty to prove a disputed fact) is regulated by arts. 10, 249 and 254 NCPC, which are stating that the parties have the duty to prove their allegations, claims and defences. The rule is complemented by the principle of the active role of the judge ${ }^{61}$.

The institution of proof standards (quantum of proof) does not exist in our system. The applicable doctrine is that of the judge's conviction intime and of the free evaluation of evidence.

The theory of evidence traditionally mentions a number of facts that don't need to be proven, namely, the presumptions ${ }^{62}$ and the well known facts (fapte notorii) ${ }^{63}$. The new Code prescribes that the court may decide that taking of evidence is not necessary to prove a fact which is publicly well known or one that is uncontested (art. 255 para. 2 NCPC); according to art. 349 para 1 NCPC, a recognition (of a fact) which was made in

\footnotetext{
${ }^{57}$ See art. 295 NCPC.

${ }^{58}$ Art. 187 NCPC.

${ }^{59}$ See art. 187 et seq. NCPC.

${ }^{60}$ Art. 358 NCPC.

${ }^{61}$ See also Leş 2010, p. 553.

${ }^{62}$ The presumptions (or 'established facts' - fapte constante) can be legal or judicial. A presumption means that a certain fact is presumed to be true (e.g., in family cases, the mother's husband is presumed to be the father of the child; the goods acquired by spouses during marriage are presumed to be common goods); against some presumptions proof to the contrary is admissible (juris tantum presumptions); other presumptions are irebuttable (juris et de jure presumptions).

${ }^{63}$ See Hilsenrad, Stoenescu, p. 179.
} 
court has the value of a total proof against the one that made the recognition. The Code also maintains the institution of the presumptions (arts. 327-329 NCPC).

According to art. 14 para. 3 NCPC, the parties have the obligation to express their opinion regarding the allegations of the opposite party.

Jura novit curia applies in our procedure ${ }^{64}$. Art. 251 NCPC states that no one is hold to prove whatever it is that the court itself is hold to have cognizance of, id est (according to art. 252) the law. The norm must nevertheless be proven when it is prescribed by an act which is not published in the Official Gazette, by international conventions, treaties and agreements which are not implemented in the internal law, and by the customary international law ${ }^{65}$.

The principle of the active role ${ }^{66}$ entails that the judge is empowered to require the parties to offer clarifications regarding the facts and legal grounds they assert, to put into discussion any legal or factual circumstances, even if these are not specified in the claim or in the defence statement, to order the taking of evidence they consider necessary and other legal measures, even if the parties oppose ${ }^{67}$.

The court can ask the claimant to complete or supplement the introductory claim before the defendant is even summoned to the trial ${ }^{68}$. There is no similar disposition in which regards the statement of the defendant.

The court can order the parties the completion of the evidence, if it appreciates it is necessary, and it can order itself the taking of new evidence (art. 254 para. 5 NCPC).

The completion of the evidence can also be ordered at the end of the trial (the judicial investigation), before the closing arguments, if its necessity results during the debates (art. $391 \mathrm{NCPC}$ ).

A party can ask the court to order a third person who is in possession of evidence, to submit it to the court ${ }^{69}$.

\footnotetext{
${ }^{64}$ See Leş 2010, p. 555 et seq.

${ }^{65}$ Art. 252 para. 2 NCPC.

${ }^{66}$ According to this principle, the judge has the duty to persist, using all legal means, in preventing any error in finding the truth in the case (Art. 22 para. 2 NCPC, in limine).

${ }^{67}$ Art. 22 para. 2 NCPC.

${ }^{68}$ Art. 200 NCPC ('The examination and the rectification of the introductory claim'). However, I do think that the legislator considered rather (or exclusively) a verification of the mere formal existance of the elements of the claim - the identification of the parties, the claims, their factual and legal grounds and the proposed evidence.

${ }^{69}$ See arts. 11, 297 NCPC.
} 


\section{$5 \quad$ Written Evidence}

A document is defined as any writing or other record which is offering information regarding a legal act or fact, regardless of the media that supports it or the mode of preservation or storage ${ }^{70}$.

An electronic document is considered as admissible evidence if it is intelligible and offers sufficiently substantial guarantees that it is completely trustworthy with regard to its contents and the identity of the person it originates from ${ }^{71}$.

According to art. 341, the photographs, photocopies, video records, disks, magnetic tapes and other similar means are considered physical evidence, as long as they were not obtained by violating the law or morality.

The electronic document makes complete proof, until rebutted by proof to the contrary. Where the medium or technology used does not allow the integrity of the document to be confirmed or denied, the document may, depending on the circumstances, be admitted as real evidence or serve as commencement of proof ${ }^{72}$.

The electronic version of a document is considered to be equivalent to a document. The method of proof would be, in this case, the document on paper that reproduces the data in the electronic version ${ }^{73}$.

Law no. 455/2001 regulates the 'extended electronic signature', stating that whenever written form is required for a legal act ad probationem or ad validitatem, an electronic document fulfils this requirement if an extended electronic signature was incorporated, attached to or logically associated with it. The extended electronic signature is one that is validated by a qualified certificate and generated by a secure signature-creation device.

Documents are categorized into authentic ${ }^{74}$ and private documents ${ }^{75}$.

An authentic document is presumed to be accurate, correct, in other words it will be considered as an absolute proof of those matters personally perceived by the official that instrumented the document, until (unless) the document is declared to be false ${ }^{76}$.

\footnotetext{
${ }^{70}$ Art. 265 NCPC.

${ }^{71}$ Art. 282 NCPC.

72 Art. 284 NCPC.

${ }^{73}$ Fodor, in Ciobanu Nicolae, p. 727.

${ }^{74} \mathrm{An}$ authentic document is one that has been attested by a competent public officer (e.g., by a notary public). See S. Spinei, Organizarea profesiilor juridice liberale, p. 213-216 (Universul Juridic, 2010).

${ }^{75}$ Or 'documents under private signature' - writings signed by the parties and not subject to any other formality.

${ }^{76} \mathrm{See}$, for the procedure of improbation, arts. 304-308 NCPC.
} 
Against the statements of the parties recorded in the document, evidence to the contrary is allowed ${ }^{77}$.

The private document which is admitted by the party who allegedly signed it makes proof unless evidence to the contrary is provided ${ }^{78}$. According to art. $301 \mathrm{NCPC}$, when a private document is presented, the party who allegedly wrote or signed it has to admit or contest the signature or the writing. In case of contestation, the court may initiate a procedure of verification of the writing, or an action of improbation (to investigate over an allegation that a document was falsified).

Other categories of documents are also considered private documents or the equivalent thereof: domestic papers and registers, registers of a business owner, a release, even unsigned and undated, inscribed by a creditor on the title of his debt, standardized contract forms, unsigned documents used in the ordinary course of business, etc. ${ }^{79}$ The correspondence between the parties can also serve as evidence.

Documents are filed in the record in the written phase or later in the trial (at least five days before the hearing); they are not read at the hearing. In the practice of the court, the judge may grant a continuance for the party to study the filed documents.

The court can order the presentation of a document which is in possession of the opposite party, of a third person or of an authority.

In principle, the parties will only produce certified copies of the documents. The original version may be also requested by the court, if verifications are necessary.

\section{$6 \quad$ Witnesses}

Witnesses have the obligation to testify.

A person can refuse to appear as a witness in only a few situations, specified by art. 317 para. 1 NCPC. According to point 1 of this text, there is no obligation to give testimony ${ }^{80}$ for the clergymen, doctors, pharmacists, lawyers, notaries public, bailiffs, mediators, midwives, physician's assistants, and any other professional that is bound by law to keep employee ${ }^{81}$ or professional secrecy ${ }^{82}$, regarding matters revealed to them in the exercise of their functions.

${ }^{77}$ See art. 270 NCPC.

${ }^{78}$ Art. 273 NCPC.

${ }^{79}$ See arts. 277, 279-281, 289-290 NCPC.

${ }^{80}$ The literal translation would be 'exemption from testifying'.

${ }^{81}$ According to Law no. 182/2002 regarding the protection of classified information, employee secrecy concerns information which, if revealed, would cause harm to a public or private legal person.

${ }^{82}$ In regard to journalists, Law no. 504/2002 on Audiovisual Media states that confidentiality of journalistic sources is guaranteed; a Court can order the revealing of a source only if necessary for protecting national security or public order (art. 7). A similar provision contains Law no. 19/2003 
According to point 2, there is no obligation to give testimony for the judges, prosecutors and civil servants, even after they left office, regarding secret circumstances they learned due to their position.

There is no obligation to give testimony also for those who would expose themselves or a closely connected person (e.g. husband, relative ${ }^{83}$ ), by testifying, to a criminal sanction or to public discredit (art. 317 para. 1 point 3 ).

A person who is in this kind of position does not have to appear in court, a written justification will suffice, unless the judge considers otherwise. The opposing party will always be able to challenge the justification.

The persons mentioned by art. 317 para. 1 point 1 (except for the clergymen) will be able to testify if released from the duty to secrecy by the interested person or legal entity, unless a legal disposition provides otherwise.

The persons mentioned by art. 317 para. 1 point 2 will also be able to testify if authorized to disclose by the institution or authority they worked for.

Art. 315 NCPC provides that certain persons cannot testify: relatives and relatives by marriage (up to and including the third degree) of the parties ${ }^{84}$; the husband, exhusband, fiancée, or domestic partner of the party; those who are in a relation of enmity or connected by interests with the party; those placed under judicial interdiction; those convicted for perjury.

According to art. 315 para. 2, if the parties agree, the persons who are in one of the first three situations can be heard as witnesses.

The witnesses will be summoned by the court. They can be also heard in the same court session where the request for witness testimony was granted. The party can also bring the witness in court ${ }^{85}$.

State secret can also prevent the taking of evidence ${ }^{86}$.

on the National Press Agency - Rompres, which mentions that the revealing of sources can only be ordered if the general public interest requires it (art. 10). Finally, the Journalists Code of Deontology (set up by the Romanian Press Club - an NGO that includes some one hundred journalists and a number of media companies) states that in Court, the journalist will observe the confidentiality of sources according to his own conscience.

${ }^{83}$ See art. 315 NCPC.

${ }^{84}$ In matters of family relations (like divorce or filiation cases), relatives and those who are in an affinity relation with the parties can testify (except for the descendants) - art. 316 NCPC.

${ }^{85}$ See arts. 311, 312 NCPC.

${ }^{86}$ See Law no. 182/2002 regarding the protection of classified information. 
Art. 319 para. 6 NCPC stipulates that the witness will only make a promise that he will tell the truth and he will not conceal anything he is aware of, if he does not want to take an oath for reasons of conscience or confession.

The court can reduce the number of proposed witnesses ${ }^{87}$.

According to art. 321 para. 3 NCPC, the witness will first answer to the questions of the court; then, to the questions asked, with the permission of the court, by the party who proposed the witness and then by the opposite party ${ }^{88}$.

If the court finds it necessary, the witness can be called again in the court for questioning; witnesses who gave contradictory testimonies can be called again to be confronted $^{89}$.

The court can also reject certain questions of the parties, of its own motion or sustaining an objection of the opposite party (if the questions: are not relevant; they are offensive; or they tend to prove a fact whose proof, according to the law, is not admissible ${ }^{90}$ ); at the request of the party, the court will set down in the records of hearings both the question and the grounds of its rejection ${ }^{91}$.

The answers of the witness are dictated by the judge to the clerk, who transcribes them ${ }^{92}$ (if necessary, the answers are rephrased by the judge).

A witness can only give oral testimony.

The evaluation of the witness testimony is also governed by the rule of the free evaluation of evidence.

There are certain facts which cannot be proven by way of witness testimony: first of all, the general rules are applicable - for the proof to be admissible, the fact must be credible, relevant ('pertinent') and conclusive ${ }^{93}$; there are also, on the other hand, some specific rules: witness evidence is not admissible if it aims to prove a legal act (contract) which has a value of more than the equivalent of $€ 60^{94}$ or if it aims to prove against the content of a written document ${ }^{95}$.

${ }^{87}$ Art. 258 NCPC.

${ }^{88}$ In court practice, the witness is allowed to tell whatever it is that he knows about the facts of the case (see Leş 2010, p. 589; Ionaşcu, p. 221).

${ }^{89}$ Art. 322 para. 1,2 NCPC.

${ }^{90}$ E.g., for not being conclusive; or if the fact is presumed by law as being certain.

${ }^{91}$ Art. 322 para 3 NCPC.

92 Art. 323 NCPC.

${ }^{93}$ See Ionaşcu, p. 41; Spinei 2012, p. 273.

${ }^{94}$ Unless one of the parties of the contract is a business owner (profesionist), in which case the rule is the admissibility of witness testimony against the said business owner (art. 309 para. 2 NCPC).

${ }_{95}$ With some exceptions - see art. 309 para. 4, 5 NCPC. 
The perjury constitutes a crime (infracțiune), being incriminated by art. 273 of the Criminal Code, which prescribes the sanction of imprisonment for between six months and three years or a fine.

Cross examination is present in our procedure - the witness of one party can be questioned by the opposite party ${ }^{96}$.

\section{$7 \quad$ Taking of Evidence}

Evidence is taken in the second stage of the process, which is called the 'instruction' or 'investigation' phase ${ }^{97}$. If necessary, supplementary evidence can also be taken in the preliminaries of the arguments phase (which in this case constitutes a prolongation of the instruction).

Some types of evidence (such as documents) are produced by the parties themselves. The witnesses can be presented by the parties themselves or they can be ordered to appear by the judge. The judge will also order the experts to appear in court if, for example, clarification on their written reports is necessary.

Once it allowed the request for evidence of the parties, the court will organize the taking of evidence. The judge can order the production of evidence, can give the necessary instructions and can impose dates and terms (deadlines), under the penalty of forfeiture/loss of the right to present evidence.

During the trial, the court can reconsider any previous disposition regarding evidence. It can order, as mentioned, the completion of evidence, and it can also appreciate that some earlier allowed evidence is no longer necessary because the facts were established by taking other means of evidence.

If there is a risk that evidence will disappear or it will be difficult to be taken later, any person who has an interest can request the immediate taking of evidence, before or during the trial ${ }^{98}$. If the request is granted, the evidence will be taken by the court. The court can also delegate a bailiff to certify (record) a situation or state of certain things, if it is possible that it will cease or change.

\subsection{Rejection of an Application to Obtain Evidence}

A request for evidence will be rejected if the proposed evidence does not fulfil the conditions of admissibility, namely if the means of evidence is not provided by the law, or if the fact to be proven is not credible, relevant and conclusive, etc.; the request can also be rejected if it is not submitted in the time-limits imposed by the law.

\footnotetext{
${ }^{96}$ Art. 321 para. 3 NCPC.

97 The stages of the process are: the preparatory written phase (when the claimant files the demand, the defendant - the defence statement, etc.); the instruction (judicial investigation) phase; the phase of the closing arguments; the deliberation and adjudication.

${ }^{98}$ See arts. 359 et seq., in the section 'The Securing of Evidence' of the NCPC.
} 
Such a ruling must be justified by the court.

A request for evidence can be submitted, at the latest, before the end of the instruction (investigation) phase, but only in limited situations ${ }^{99}$.

The parties are obliged to offer some specific details regarding the evidence they request: if they are requesting the taking of witness testimony, they have to mention the full name and address of the witness in the introductory claim or in the defence statement; the parties will also have to indicate what facts are going to be established with each means of evidence they are requesting to be taken.

The facts established in an administrative procedure have no legal force before the civil court. The facts established in other civil proceedings are hold as proven for the parties in those proceedings. A decision rendered by a criminal court is binding for the civil court regarding the existence of the criminal act, the identity of the perpetrator and its culpability.

\subsection{The Hearing}

The evidence is taken in court, at the hearings ${ }^{100}$, by the same judge or panel that decides the case (in accordance with the principle of directness).

Our procedure also provides for an alternative procedure - the taking of evidence by lawyers or legal counsel. The parties can agree to employ this procedure, unless the case regards matters such as the personal capacity or family relations.

As an exception from the principle of directness, a court can require assistance from another court for the taking of evidence, by way of the 'letter/commission rogatory', if there are solid reasons for which the taking of evidence cannot be done by the requesting court ${ }^{101}$.

The judicial clerks cannot take evidence.

The court can order the taking of supplementary evidence in the preliminaries of the last stage of the trial (the closing arguments phase), if it appreciates it necessary.

\footnotetext{
${ }^{99}$ If the necessity of the evidence is determined by the modification of the claim; the necessity of the evidence appears during the trial and the party was not able to anticipate it; the party was unable to submit the evidence for solidly justifiable reasons; the taking of evidence does not determine the delay of the trial; or if all the parties agree to the taking of evidence (art. 254 para. 2 NCPC).

${ }^{100} \mathrm{~A}$ case is judged in a series of court sessions (hearings). If complex evidence is necessary, the court will structure the taking of such evidence during a number of hearings (see also art. 260 NCPC).

${ }^{101}$ Art. 261 NCPC.
} 
Different types of evidence will be proposed by the parties and allowed or ordered sua sponte by the court, depending on the nature of the case and the (free) evaluation of the judge.

The parties have the right to be present at the taking of evidence. They are not obliged to be present.

In our civil procedure, the witnesses have to be present in the court. The possibility of a written or recorded testimony is not stipulated, nor it is the possibility of the testimony by video-link or similar means.

\subsection{Witnesses}

The witnesses will be summoned by the court. They can also be brought by the parties themselves. There is no requirement for a written witness statement to be presented first. The summons are written and they are delivered by court clerks, postal and courier services or bailiffs ${ }^{102}$.

The witness will swear an oath. If he/she does not want to take an oath for reasons of conscience or confession, the witness will only make a promise that he will tell the truth and he will not conceal anything he is aware of ${ }^{103}$. There is no difference in the evaluation of the testimony based on whether it was done under oath or under promise.

Each witness is heard separately, those who did not testify yet not being allowed to be present in the courtroom. After being heard, the witness must remain in the courtroom $^{104}$.

The Code of Civil Procedure doesn't provide any rule regarding the preparation of witnesses. A prior questioning of the witness by the legal council is practiced. There is a number of prescriptions in the legislation of the legal professions which stipulate the principle of legality ${ }^{105}$. The act of instigating to perjury, as well as the attempt to determine perjury are sanctioned by the Criminal Code. A conviction for such crimes also determines the disbarment of the lawyer.

\subsection{Expert Witnesses}

The questions for the expert are usually proposed by the parties, but they have to be approved by the court. The court can rephrase the questions, reject questions or ask additional questions.

\footnotetext{
${ }^{102}$ See art. 154 NCPC.

${ }^{103}$ See art. 319 NCPC.

104 Art. 321 NCPC.

${ }^{105}$ See Spinei 2010, p. 63.
} 
The procedure of obtaining the expert opinion/report is distinctly regulated by the Code of Civil Procedure ${ }^{106}$.

The judge can approve or reject the party's request for an expert report, or can order sua sponte the report. He can appoint and replace the expert (if, for example, he does not produce the report in reasonable time), decide on an application for recusal of the expert, decide over the questions to be asked to the expert and the objections of the parties regarding the report, etc.

The party who is requesting the expert report will usually propose the questions for the expert, but the questions can be formulated also by the opposing party.

Both parties can indicate a certain expert to give the report, request the rejection or replacement of the appointed expert, offer clarifications or explanations for the expert, formulate objections to the report.

If the expert can give his opinion at once, he will be heard in court. If research, inspections on site or explanations of the parties are necessary, he will produce a written report, answering the questions ('objectives') of the court.

The experts are selected from a list of authorized experts, kept by the Ministry of Justice and also by the Local Bureau for Expert Reports. If the parties don't agree on the appointment of an expert, the court will appoint the expert by sortition. An expert can be rejected (recused) by the parties, on grounds of incompatibility (because of interest or bias), which are provided by the Code of Civil procedure ${ }^{107}$.

The party can present a private expert report (an 'extra-judicial' report), alongside the introductory claim or later during the trial, but in order to be accepted as evidence, the opposing party must agree. The court can always, nevertheless, order a judicial report.

The parties have also the possibility to appoint consultant-experts, which will be able to participate to the activities involved in the process of carrying out the judicial report (the consultants can offer information and clarifications, can ask questions and formulate observations, and can also produce their own report ${ }^{108}$ ).

The expenses for the expert report are usually paid in advance by the party who requests for the report.

If the court orders an expert report, it will determine the costs and the party who will advance the payments. It can also determine that costs are to be paid by both parties ${ }^{109}$.

\footnotetext{
${ }^{106}$ Arts. 330-340 NCPC.

${ }^{107}$ See art. 41 et seq. NCPC.

${ }^{108}$ Art. 330 para. 5 NCPC.

${ }^{109}$ See art. 262 NCPC.
} 
The party who loses the case will finally have to support all the costs of the trial, if requested by the prevailing party.

The judge is bound by the content of written evidence, as well as by the written expert opinions, as long as the report remains unchallenged ${ }^{110}$.

\section{Costs and Language}

\subsection{Costs}

The legal expenses entail court fees ${ }^{111}$, attorney's fees, expert fees, expenses with witnesses (travelling, compensation for loss caused by the obligation to be present in court), expenses with transportation and accommodation, and any other litigation expenses $^{112}$.

Each party will pay his or her own expenses relating to the taking of evidence. At the end of the lawsuit, the unsuccessful party will pay, if requested, all the costs caused/incurred by the trial to the prevailing party. Some of the requested expenses can be reduced by the court. The court will examine the request and only award the expenses which it appreciates are reasonable ${ }^{113}$.

The expenses with the evidence have to be made, usually, with the purpose of bringing the evidence in the court, therefore before the evidence is taken. Art. 262 NCPC prescribes that if necessary, the court will determine the costs of the taking of the evidence and will instruct the party who requested the evidence to demonstrate the payment of those expenses at once or by a certain date. If the payment is not made, the party may be penalised with the loss of the right to present the evidence, which can lead to the rejection of the introductory claim.

If the evidence is ordered by the court, it will also determine the costs and order which party (or if both parties) will make the payment.

110 The parties have the possibility to challenge the conclusions of a report and obtain clarifications, completions or a second report.

${ }^{111}$ See Government Ordinance no. 80/2013 regarding the court fees ('judicial taxes'). In our system, court fees are to be paid by those persons who are filing claims and petitions in courts. In certain matters, the plaintiff is exempt from paying court fees.

${ }^{112}$ Art. 451 NCPC.

${ }^{113}$ See, on the possibility of reducing costs with the attorney's and expert fees, art. 451 para. 2, 3. See, on the principle of only awarding costs that are necessarily incurred and reasonable as to quantum, Court of Cassation, Commercial Division, decision no. 405/2010 and Court of Cassation, I ${ }^{\text {st }}$ Civil Division, decision no. 6913/2012, which are following the ECHR case-law (apud Adina Nicolae, in Ciobanu, Nicolae, p. 1023, 1025.) 
The court also practices sometimes the ordering of production of an expert report even if the expert fee was not paid. The court will issue, in this case, an order for the payment of the fee, which the expert can enforce against the party ${ }^{114}$.

If the party is lacking the financial means, the cost of the expert's and the interpreter's fee can be covered by public legal aid funds ${ }^{115}$.

According to art. 18 of the Regulation 1206/2001, if the requested court so requires, the requesting court shall ensure the reimbursement, without delay, of the fees paid to experts and interpreters, and the costs occasioned by the application of article 10 para. 3 and 4 of the Regulation.

\subsection{Language and Translation}

Translation or interpretation is provided by accredited professionals.

Documents in foreign languages are translated in Romanian by sworn translators.

When a witness speaking in a foreign language is being questioned, an interpreter is always appointed.

The costs of interpretation are covered by the interested party.

\section{$9 \quad$ Unlawful Evidence}

Our legal theory did not consistently structure the concept of unlawful evidence.

Disparate observations and legal texts are allowing, nevertheless, some considerations to be made.

The notion of 'illegal evidence' may refer to the proposition of such means of evidence which is not explicitly listed by the law, to evidence that does not meet the general conditions of admissibility, to evidence taken without observing other procedural requirements, or to false evidence (such as production of forged documents, false testimony etc.).

A general principle of the inadmissibility of illegally obtained evidence is not explicitly stated by the Code of Civil Procedure ${ }^{116}$.

114 See Court of Appeal Braşov, Civil Division, decision no. 16/M/2008, on http://www.jurisprudenta.org/ (accessed 20 Dec. 2013); Buzău Tribunal, judgment no. 1667/2011; Court of Cassation, II ${ }^{\text {nd }}$ Civil Division, decision no. 1425/2012, on http://legeaz.net/spete-civil-iccj-2012/decizia-1425-2012 (accessed 20 Dec. 2013).

${ }_{115}^{11}$ See Government Ordinance no. 51/2008 regarding the public legal aid in civil matters.

${ }^{116}$ The draft of the new Code of Criminal Procedure explicitly prescribes that illegally obtained evidence cannot be used in the criminal lawsuit (see art. 100). 
However, the Romanian Constitution states that the public authorities respect and protect the private and family life; that home, the secrecy of correspondence, phone and other means of communication, are inviolable ${ }^{117}$. Moreover, Romania ratified the European Convention on Human Rights.

The principle of legality, prescribed by art. 7 of the new Code of Civil Procedure, also states that the civil process takes place according to the provisions of the law and that the judge has the duty to ensure the observation of the provisions of the law regarding the attainment of the rights and the fulfillment of the duties of the parties.

The new code also contains a particular rule, which states that photographs, photocopies, video records, disks, magnetic tapes and other similar means are considered physical evidence, as long as they were not obtained by violating the law or morality (art. $341 \mathrm{NCPC}$ ).

Art. 195 of the Criminal Code is protecting communication by incriminating the illegal opening, theft, destruction, detaining, etc., of correspondence (mail) and the illegal interception of phone and other means of communication.

There is mentioned in our civil procedure literature that the use of letters as evidence by their addressee or by a third person is not always free (unrestricted); such use may depend upon their content ${ }^{118}$ and the manner in which the letter was obtained ${ }^{119}$.

These may be reasons for a court to proceed cautiously when confronted to evidence that contravenes to the aforementioned principles and rules.

Civil courts can annul illegal evidence; the exclusion of certain taken evidence is also practiced (in the sense that the evidence is overlooked/not considered), if there are justifiable grounds. The fact that evidence was illegally obtained may represent such grounds.

\section{The Report about the Regulation No 1206/2001}

https://mail-attachment.googleusercontent.com/attachment/u/0/?ui=2\&ik=2a2db81c06 $\&$ view=att \&th=13f0f97163496afb\&attid=0.4\&disp=inline \&realattid=fhhj6lu5y3\&safe =1\&zw\&saduie=AG9B_P8EO8b4IziLZq4qoq2cr9qs\&sadet=1380110165810\&sads=7 W4b6HEaZBZTan6x62SUMJhic1s (Please, see pages 104-107.)

Please advise the accuracy of the information regarding your legal system and in what sense are the reported treaties more favourable than the system established under the Regulation No 1206/2001.

There are no bilateral treaties concluded between Romania and other Member States ${ }^{120}$.

${ }^{117}$ See arts. 26, 27, 28 of the Constitution of Romania.

${ }^{118}$ For example, the confidential or private character of the information may be considered.

${ }^{119}$ See Hilsenrad, Stoenescu, p. 199. 
Romania and Croatia signed in 2004 an Intergovernmental Protocol on Succession regarding the agreements between Romania and the former Socialist Federal Republic of Yugoslavia. According to the Protocol, Croatia is successor to the Treaty regarding Judicial Cooperation, concluded in $1961^{121}$.

\section{Table of Authorities}

Please, provide information on the competent authorities referred to in Article 3(3) in your national legal system and give indication of relevant statutes (which acts are applicable, the name in national language, does the English translation exist, are there some important cases, name of the case and link).

According to art. 37 of Law no. 189/2003 regarding international judicial cooperation in civil and commercial matters, the Ministry of Justice (Ministerul Justiției) is the competent authority referred to in Article 3(3).

The organization and functioning of the Ministry of Justice are regulated by Government Decision no. 652/2009 ${ }^{122}$.

120 See http://www.just.ro/Sectiuni/Cooperarejudiciar\%C4\%83interna\%C5\%A3ional\%C4\%83/ Ghiddecooperare\%C3\%AEnmateriecivil\%C4\%83\%C5\%9Ficomercial\%C4\%83/Conven\%C5\%A 3iibilaterale/tabid/821/Default.aspx.

${ }^{121}$ Ibid.

${ }^{122}$ See http://www.cdep.ro/pls/legis/legis_pck.htp_act?ida=89628. 
Evidence in Civil Law - Romania

S. Spinei

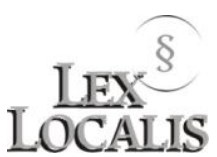

\section{Part II - Synoptical Presentation}

\section{$1 \quad$ Synoptic Tables}

\subsection{Ordinary/Common Civil Procedure Timeline}

\begin{tabular}{|c|c|c|c|c|}
\hline $\begin{array}{l}\text { Phase } \\
\#\end{array}$ & $\begin{array}{l}\text { Name of the Phase } \\
\text { Name of the Phase } \\
\text { in National } \\
\text { Language }\end{array}$ & $\begin{array}{l}\text { Responsible } \\
\text { Subject }\end{array}$ & $\begin{array}{l}\text { Duties of the Responsible } \\
\text { Subject (related only to } \\
\text { Evidence) and } \\
\text { Consequences of their } \\
\text { Breach }\end{array}$ & $\begin{array}{l}\text { Rights (related only to } \\
\text { Evidence) of the } \\
\text { Responsible Subject }\end{array}$ \\
\hline I. & $\begin{array}{l}\text { First instance } \\
\text { court proceedings } \\
(\text { Judecata în prima } \\
\text { instanță) }\end{array}$ & & & \\
\hline 1. & $\begin{array}{l}\text { Written phase } \\
\text { (sesizarea } \\
\text { instanței) }\end{array}$ & & & \\
\hline 1.1. & $\begin{array}{l}\text { Introductory claim } \\
\text { (cererea de } \\
\text { chemare } \hat{\imath} n \\
\text { judecată) }\end{array}$ & $\begin{array}{l}\text { Plaintiff } \\
\text { (reclamant) }\end{array}$ & $\begin{array}{l}\text { - request evidence: } \\
\text { preclusion } \\
\text { - attach copies of } \\
\text { documents, indicate name, } \\
\text { address of witnesses: } \\
\text { preclusion or annulment of } \\
\text { the claim }\end{array}$ & $\begin{array}{l}\text { - request the summoning } \\
\text { of the defendant for } \\
\text { responding to } \\
\text { interrogation, and other } \\
\text { measures for the taking of } \\
\text { evidence } \\
\text { - request the securing of } \\
\text { evidence }\end{array}$ \\
\hline 1.2 . & $\begin{array}{l}\text { Examination and } \\
\text { rectification of the } \\
\text { introductory claim } \\
\text { (verificarea şi } \\
\text { regularizarea } \\
\text { cererii) }\end{array}$ & $\begin{array}{l}\text { Court } \\
\text { (instanța), } \\
\text { plaintiff }\end{array}$ & $\begin{array}{l}\text { Plaintiff: comply with court } \\
\text { instructions: annulment (or } \\
\text { preclusion) }\end{array}$ & $\begin{array}{l}\text { Court: instruct the plaintiff } \\
\text { to complete or supplement } \\
\text { the introductory claim }\end{array}$ \\
\hline 1.3 & $\begin{array}{l}\text { Service of claim } \\
\text { (comunicarea } \\
\text { cererii de chemare } \\
\text { in judecată) }\end{array}$ & Court & $\begin{array}{l}\text { - advise the defendant on } \\
\text { his obligation to file the } \\
\text { statement of defence, and } \\
\text { on the sanction of } \\
\text { preclusion in case of non- } \\
\text { compliance }\end{array}$ & \\
\hline 1.4 . & $\begin{array}{l}\text { Statement of } \\
\text { defence } \\
\text { (întâmpinarea) }\end{array}$ & $\begin{array}{l}\text { Defendant } \\
\text { (pârât) }\end{array}$ & $\begin{array}{l}\text { - request evidence: } \\
\text { preclusion } \\
\text { - attach copies of } \\
\text { documents, indicate name, } \\
\text { address of witnesses: } \\
\text { preclusion }\end{array}$ & \\
\hline
\end{tabular}




\begin{tabular}{|c|c|c|c|c|}
\hline 1.5 . & $\begin{array}{l}\text { Counterclaim } \\
\text { (cererea } \\
\text { reconvenţională) }\end{array}$ & Defendant & $\begin{array}{l}\text { - request evidence: } \\
\text { preclusion } \\
\text { - attach copies of } \\
\text { documents, indicate name, } \\
\text { address of witnesses: } \\
\text { preclusion or annulment of } \\
\text { the claim }\end{array}$ & \\
\hline 1.6. & $\begin{array}{l}\text { Response to the } \\
\text { statement of } \\
\text { defence (răspuns la } \\
\text { intâmpinare) }\end{array}$ & Plaintiff & $\begin{array}{l}\text { - no rules prescribed in the } \\
\text { Code of Civil Procedure }\end{array}$ & $\begin{array}{l}\text { - no rules prescribed in the } \\
\text { Code of Civil Procedure }\end{array}$ \\
\hline 1.7. & $\begin{array}{l}\text { Summons } \\
\text { (citarea şi } \\
\text { comunicarea } \\
\text { actelor de } \\
\text { procedură) }\end{array}$ & Court & & $\begin{array}{l}\text { - calling the parties for } \\
\text { responding to interrogation } \\
\text { - order the parties to } \\
\text { submit documents } \\
\text { - order other measures }\end{array}$ \\
\hline 1.8. & $\begin{array}{l}\text { Preparation of the } \\
\text { trial } \\
\text { (pregătirea } \\
\text { judecății) }\end{array}$ & Court & & $\begin{array}{l}\text { - can order measures for } \\
\text { the taking of evidence }\end{array}$ \\
\hline \multirow[t]{3}{*}{2.} & $\begin{array}{l}\text { Instruction phase } \\
\text { (cercetarea } \\
\text { judecătorească) }\end{array}$ & & & \\
\hline & $\begin{array}{l}\text { First hearing } \\
\text { (primul termen de } \\
\text { judecată la care } \\
\text { părțile sunt legal } \\
\text { citate) }\end{array}$ & $\begin{array}{l}\text { Court, parties } \\
\text { (părți) }\end{array}$ & $\begin{array}{l}\text { Court: } \\
\text { - advises parties they can } \\
\text { agree to the taking of } \\
\text { evidence by their lawyers } \\
\text { - rules on the requests of } \\
\text { evidence of the parties }\end{array}$ & $\begin{array}{l}\text { Parties: } \\
\text { - can opt for the procedure } \\
\text { of the taking of evidence } \\
\text { by lawyers }\end{array}$ \\
\hline & $\begin{array}{l}\text { Hearings (termene } \\
\text { de judecată) }\end{array}$ & Parties, court & $\begin{array}{l}\text { Parties: } \\
\text { - present evidence: } \\
\text { preclusion, which may lead } \\
\text { to the dismissal of the claim } \\
\text { - pay for the costs with the } \\
\text { taking of evidence: } \\
\text { preclusion, which may lead } \\
\text { to the dismissal of the claim } \\
\text { - comply with the orders of } \\
\text { the court: same } \\
\text { consequences as supra } \\
\text { Court: takes the evidence }\end{array}$ & $\begin{array}{l}\text { Court: } \\
\text { - orders the taking of any } \\
\text { evidence it considers } \\
\text { necessary } \\
\text { - orders any measures for } \\
\text { the taking of evidence } \\
\text { - imposes dates and terms } \\
\text { - orders the securing of } \\
\text { evidence } \\
\text { Parties: } \\
\text { - request the securing of } \\
\text { evidence }\end{array}$ \\
\hline 3. & $\begin{array}{l}\text { Closing arguments } \\
\text { (dezbaterea în fond } \\
\text { a procesului) }\end{array}$ & Parties, court & & $\begin{array}{l}\text { Court: may order new } \\
\text { evidence }\end{array}$ \\
\hline 4.1. & $\begin{array}{l}\text { Deliberation } \\
\text { (deliberarea) }\end{array}$ & Court & & $\begin{array}{l}\text { Can decide the resuming } \\
\text { of instruction phase and } \\
\text { order new evidence }\end{array}$ \\
\hline 4.2 . & $\begin{array}{l}\text { Adjudication } \\
\text { (pronunțarea } \\
\text { hotărârii) } \\
\end{array}$ & Court & & \\
\hline II. & $\begin{array}{l}\text { Appelate } \\
\text { proceedings } \\
\text { (Judecata în căile } \\
\text { de atac) }\end{array}$ & & & \\
\hline 1. & $\begin{array}{l}\text { First appeal } \\
\text { proceedings }(\mathrm{Apel})\end{array}$ & Court, parties & & $\begin{array}{l}\text { - parties can request new } \\
\text { evidence }\end{array}$ \\
\hline
\end{tabular}




\begin{tabular}{|l|l|l|l|l|}
\hline & & & & $\begin{array}{l}\text { - court can order new } \\
\text { evidence }\end{array}$ \\
\hline 2. & $\begin{array}{l}\text { Second appeal } \\
\text { proceedings } \\
\text { (Recurs) }\end{array}$ & Court, parties & & $\begin{array}{l}\text { - only documents } \\
\text { admissible as evidence }\end{array}$ \\
\hline
\end{tabular}

\subsection{Basics about Legal Interpretation in Romanian Legal System}

There is no protocol for interpretation of substantive legal rules and procedural rules.

\subsection{Functional Comparison}

\begin{tabular}{|c|c|c|c|c|}
\hline $\begin{array}{l}\text { Means } \\
\text { of Taking } \\
\text { Evidence }\end{array}$ & National Law & Bilateral Treaties & $\begin{array}{c}\text { Multilateral } \\
\text { Treaties }\end{array}$ & $\begin{array}{c}\text { Regulation } \\
1206 / 2001\end{array}$ \\
\hline $\begin{array}{c}\text { Hearing of } \\
\text { Witnesses by } \\
\text { Mutual Legal } \\
\text { Assistance } \\
\text { (Legal Aid) }\end{array}$ & $\begin{array}{l}\text { Possible according } \\
\text { to art. } 261 \text { NCPC: } \\
\text { 'If, for objective } \\
\text { reasons, the taking } \\
\text { of evidence can } \\
\text { only be done } \\
\text { outside the } \\
\text { jurisdiction of the } \\
\text { court, it may be } \\
\text { done by way of } \\
\text { letter rogatory, by } \\
\text { another court of the } \\
\text { same rank or even } \\
\text { by a lower court'. } \\
\text { In the practice of } \\
\text { the courts, the } \\
\text { requesting court } \\
\text { will offer the } \\
\text { necessary } \\
\text { information } \\
\text { regarding the case } \\
\text { and the } \\
\text { circumstances to be } \\
\text { proven. } \\
\text { Role of judge } \\
\text { - make the request } \\
\text { - offer information } \\
\text { for the requested } \\
\text { court }\end{array}$ & $\begin{array}{l}\text { The most recent act } \\
\text { governing } \\
\text { international judicial } \\
\text { cooperation in civil } \\
\text { and commercial } \\
\text { matters is Law no. } \\
\text { 189/2003. } \\
\text { Romania has } \\
\text { concluded a number } \\
\text { of bilateral treaties } \\
\text { regarding judicial } \\
\text { cooperation, which } \\
\text { comprise rules } \\
\text { regarding the taking } \\
\text { of evidence in civil } \\
\text { or commercial } \\
\text { matters, with } \\
\text { Algeria, North } \\
\text { Korea, Cuba, } \\
\text { Morocco, Mongolia, } \\
\text { Moldova, Serbia, } \\
\text { Syria, Tunisia, } \\
\text { Albania, Bosnia and } \\
\text { Herzegovina, China, } \\
\text { Egipt, Macedonia, } \\
\text { Russia, Turkey, } \\
\text { Ukraine. } \\
\text { Role of judge } \\
\text { - make the request } \\
\text { - offer information } \\
\text { for the requested } \\
\text { court (the nature of } \\
\text { the } \\
\text { procedure/indication } \\
\text { of the case for which } \\
\text { evidence is } \\
\text { necessary; name and } \\
\text { address of witnesses; }\end{array}$ & Not applicable & $\begin{array}{l}\text { Role of judge } \\
\text { - make the request } \\
\text { - offer information } \\
\text { for the requested } \\
\text { court (names and } \\
\text { addresses of the } \\
\text { parties to the } \\
\text { proceedings and } \\
\text { their } \\
\text { representatives, if } \\
\text { any; nature and } \\
\text { subject matter of } \\
\text { the case, brief } \\
\text { statement of the } \\
\text { facts; name and } \\
\text { address of the } \\
\text { person to be } \\
\text { examined; } \\
\text { questions to be } \\
\text { addressed to the } \\
\text { person to be } \\
\text { examined or a } \\
\text { statement of the } \\
\text { facts about which } \\
\text { he is to be } \\
\text { examined; } \\
\text { reference to a right } \\
\text { to refuse to testify } \\
\text { under the law of } \\
\text { the Member State } \\
\text { of the requesting } \\
\text { court; any } \\
\text { requirement that } \\
\text { the examination is } \\
\text { to be carried out } \\
\text { under oath or } \\
\text { affirmation in lieu } \\
\text { thereof, and any }\end{array}$ \\
\hline
\end{tabular}




\begin{tabular}{|c|c|c|c|c|}
\hline & & $\begin{array}{l}\text { the questions for } \\
\text { witnesses/the } \\
\text { circumstances to be } \\
\text { clarified). } \\
\text { The Ministries of } \\
\text { Justice in the States } \\
\text { Parties will ensure } \\
\text { communication } \\
\text { between the } \\
\text { requesting and the } \\
\text { requested court. }\end{array}$ & & $\begin{array}{l}\text { special form to be } \\
\text { used, etc. (art. 4). } \\
\text { - may be present } \\
\text { and participate to } \\
\text { the performance of } \\
\text { the taking of } \\
\text { evidence (art. 12) }\end{array}$ \\
\hline $\begin{array}{c}\text { Hearing of } \\
\text { Witnesses by } \\
\text { Video- } \\
\text { conferencing } \\
\text { with Direct } \\
\text { Asking of } \\
\text { Questions }\end{array}$ & $\begin{array}{l}\text { Method not } \\
\text { prescribed by the } \\
\text { Code of Civil } \\
\text { Procedure. }\end{array}$ & $\begin{array}{l}\text { Method not } \\
\text { prescribed by Law } \\
\text { no. } 189 / 2003 \text {, nor by } \\
\text { the treaties. }\end{array}$ & Not applicable & $\begin{array}{l}\text { Role of judge } \\
\text { - make the request } \\
\text { - in the procedure } \\
\text { of taking of } \\
\text { evidence by the } \\
\text { requested court } \\
\text { (art. 10), the } \\
\text { requesting judge } \\
\text { may participate } \\
\text { (also by use of } \\
\text { VCF) to the } \\
\text { procedure and may } \\
\text { ask questions (arts. } \\
10 \text { para. } 4,12 \text { ). } \\
\text { - in the procedure } \\
\text { of direct taking of } \\
\text { evidence by the } \\
\text { requesting court } \\
\text { (art. } 17 \text { ), the } \\
\text { requesting judge } \\
\text { may perform the } \\
\text { procedure also by } \\
\text { use of VCF. }\end{array}$ \\
\hline $\begin{array}{l}\text { Direct Hearing } \\
\text { of Witnesses by } \\
\text { Requesting } \\
\text { Court in } \\
\text { Requested } \\
\text { Country }\end{array}$ & $\begin{array}{l}\text { Method not } \\
\text { prescribed by the } \\
\text { Code of Civil } \\
\text { Procedure. }\end{array}$ & $\begin{array}{l}\text { Method not } \\
\text { prescribed by Law } \\
\text { no. } 189 / 2003 \text {, nor by } \\
\text { the treaties. }\end{array}$ & Not applicable & $\begin{array}{l}\text { Role of judge } \\
\text { - make the request } \\
\text { - hear the } \\
\text { witnesses }\end{array}$ \\
\hline
\end{tabular}

\begin{tabular}{|c|l|l|l|l|}
\hline $\begin{array}{c}\text { Legal } \\
\text { Regulation }\end{array}$ & National Law & $\begin{array}{c}\text { Bilateral } \\
\text { Treaties } \\
\text { of Taking } \\
\text { Evidence }\end{array}$ & $\begin{array}{c}\text { Multilateral } \\
\text { Treaties }\end{array}$ & Regulation 1206/2001 \\
\hline $\begin{array}{c}\text { Hearing of } \\
\text { Witnesses by } \\
\text { Mutual Legal } \\
\text { Assistance } \\
\text { (Legal Aid) }\end{array}$ & $\begin{array}{l}\text { Role of judge } \\
\text { - hear the witness }\end{array}$ & $\begin{array}{l}\text { The judge will } \\
\text { apply the } \\
\text { Romanian } \\
\text { procedural rules. }\end{array}$ & Not applicable & $\begin{array}{l}\text { Role of judge } \\
\text { - hear the witness }\end{array}$ \\
\hline
\end{tabular}




\begin{tabular}{|c|l|l|l|l|}
\hline $\begin{array}{c}\text { Hearing of } \\
\text { Witnesses by } \\
\text { Video- } \\
\text { conferencing } \\
\text { with Direct } \\
\begin{array}{c}\text { Asking of } \\
\text { Questions } \\
\text { prescribed by the } \\
\text { Code of Civil } \\
\text { Procedure. }\end{array}\end{array}$ & $\begin{array}{l}\text { Method not } \\
\text { prescribed by the } \\
\text { treaties. }\end{array}$ & Not applicable & $\begin{array}{l}\text { Role of judge } \\
\text { in the procedure of } \\
\text { taking of evidence by the } \\
\text { requested court (art. 10), } \\
\text { the requested judge will } \\
\text { hear the witnesses, } \\
\text { provide access to the } \\
\text { technical means and make } \\
\text { necessary arrangements } \\
\text { for the requesting judge to } \\
\text { participate. } \\
\text {-in the procedure of direct } \\
\text { taking of evidence by the } \\
\text { requesting court (art. 17), } \\
\text { the requested judge } \\
\text { provides access to the } \\
\text { technical means and may } \\
\text { take part to the taking of } \\
\text { evidence. }\end{array}$ \\
\hline $\begin{array}{c}\text { Direct Hearing } \\
\text { of Witnesses } \\
\text { by Requesting } \\
\text { Court in } \\
\text { Requested } \\
\text { Country }\end{array}$ & $\begin{array}{l}\text { Method not } \\
\text { prescribed by the } \\
\text { Code of Civil } \\
\text { Procedure. }\end{array}$ & $\begin{array}{l}\text { Method not } \\
\text { prescribed by the } \\
\text { treaties. }\end{array}$ & Not applicable & $\begin{array}{l}\text { - may be assigned to take } \\
\text { part to the taking of } \\
\text { evidence } \\
\text { (art. 17) }\end{array}$ \\
\hline
\end{tabular}


Evidence in Civil Law - Romania

Sebastian Spinei

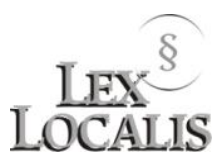

\section{References}

\section{Table of Cases}

Court of Cassation ${ }^{123}$, Commercial Division (Secția Comercială), decision no. 405/2010

Court of Cassation, Ist Civil Division, decision no. 6913/2012

Court of Cassation, IInd Civil Division, decision no. 1425/2012

Court of Appeal Braşov, Civil Division, decision no. 16/M/2008

Buzău Tribunal, judgment no. 1667/2011

A.M.M. v. Romania, no. 2151/10, ECHR 057 (2012)

\section{Bibliography}

Viorel Mihai Ciobanu, Drept procesual civil (Universitatea din Bucureşti, 1986)

Viorel Mihai Ciobanu, Marian Nicolae (coord.), Noul cod de procedură civilă: comentat şi adnotat (Universul Juridic, 2013)

Ion Deleanu, Tratat de procedură civilă (2nd ed., C.H. Beck, Bucharest, 2007)

Ion Deleanu, Tratat de procedură civilă, vol. I (Wolters Kluwer Romania, 2010)

Arthur Hilsenrad, Ilie Stoenescu, Procesul civil în RPR (Editura Ştiințifică, 1957)

Aurelian Ionaşcu, Probele în procesul civil (Editura Ştiinţifică, 1969)

Ioan Leş, Tratat de drept procesual civil (5th ed., C.H. Beck, Bucharest, 2010)

Ioan Leş, Instituţii judiciare contemporane (C.H. Beck, Bucharest, 2007)

Grațian Porumb, Codul de procedură civilă comentat şi adnotat (Editura Ştiințifică, 1962)

Sebastian Spinei, Organizarea profesiilor juridice liberale (Universul Juridic, 2010)

Sebastian Spinei, Considerations on the Romanian legal profession system, in A.

Uzelac, C.H. van Rhee (eds.), The Landscape of the Legal Professions in Europe and the USA: Continuity and Change (Intersentia, 2011)

Sebastian Spinei, Rules of Evidence in Romanian Civil Procedure and their impact on Truth and Efficiency, in C.H. van Rhee, A. Uzelac (eds.), Truth and Efficiency in Civil Litigation (Intersentia, 2012)

123 (Romanian) Court of Cassation (High Court of Cassation and Justice - Innalta Curte de Casație şi Justiție). It is the highest ourt in the Judicial system and the court of final appeal (recurs). 